\title{
APOLOGIES IN BUSINESS COMMUNICATION
}

\author{
Laura Čubajevaitè, Jūratè Ruzaitè
}

\begin{abstract}
The aim of the present paper is to examine the routine of apologizing in spoken business communication. Being face-threatening acts, apologies are of special importance in communication. Since apologies express sincerity and are remedial acts, apologizing helps to enhance mutual respect and to keep the relationship between colleagues stable, which is especially important in business communication. The present analysis focuses on four main expressions of explicit apologies, i.e. apologies with sorry, I apologise, pardon and excuse $m e$. The data have been obtained from the sub-corpus of the British National Corpus, which includes transcripts of business communication and amounts to $1,321,844$ words. The analysis accounts for the general frequency of different forms of apology in business communication as well as their frequency in relation to gender. The paper also focuses on the most typical patterns of apologies and argues that apologies range from neutral to highly emphatic or tentative. Finally, the present analysis investigates what is commonly apologised for in business settings.
\end{abstract}

Keywords: apologies, face-saving, politeness, gender, situational context, English

\section{Introduction}

The present paper discusses the routine of apologizing in spoken business communication. Apologies are of special importance in any communication since they have illocutionary force and thus are considered as speech acts; importantly, they are face-threatening acts. By admitting his/her fault, the speaker may lose face; therefore, to lessen the face-threat, special politeness strategies are required for an apology. When apologizing, most commonly speakers follow a highly predictable communicative routine to make the apology less personal and thus less facethreatening. On the other hand, apologizing is an act of expressing sincerity and a way of compensating for some damage caused to the hearer(s); thus apologizing 
helps to enhance mutual respect and to keep the relationship between colleagues stable. In business communication, where stable partnership and mutual respect are especially significant, apologies play a special role.

The present analysis focuses on four main expressions of explicit apologies, i.e. apologies with sorry, I apologise, pardon and excuse me. Implicit apologies have not been taken into account since, as Robin Tolmach Lakoff (2001: 201) rightly observes, apologies in general (and especially the implicit ones) are "hard to identify, define, or categorize". The analysis is primarily based on the corpus approach. The data have been obtained from the sub-corpus of the British National Corpus, which includes transcripts of business communication and amounts to 1,321,844 words. To make the data related to different genders comparable and to compensate for the uneven number of the words uttered by men and women in the corpus, relative frequencies (per 1 million words) will be calculated and will be presented in the analysis instead of absolute numbers.

The present analysis will focus on several aspects of explicit apologies. First of all, the general frequency of different forms of apologies will be examined. Their frequency will also be related to the social factor of gender to see whether male or female speakers apologise more extensively and whether they have any preference for different forms of apologies. Following the existing stereotypes, it can be hypothesized that women are more apologetic than men. Another aspect that will be studied is the usage patterns, which mainly include syntactic structures of different apologies. Finally, the paper will attempt to examine apologies on the pragmatic level by taking into account what is commonly apologised for in business settings. All these different aspects and levels of analysis will be related to the contextual factors, or situational features. The investigation will not take into account the phonological level since the nature of the available data does not allow us to do that. To limit the scope of the investigation, the turns following apologies are not analysed in greater detail either. This important aspect of the apologizing routine could be a focus of a separate study.

\section{Theoretical preliminaries}

The phenomenon of "the ritual organization of social encounters" was pointed to and discussed at length by Erving Goffman (1967: 45), who argues that human "interaction is organized on ritual principles" (ibid.). Conversational rituals or routines typically involve thanking, apologies, requests, offers and compliment responses. Apologies, just as some other conversational routines, have been studied rather extensively (see, for example, Owen 1983; Olshtain 1989; Vollmer, Olshtain 1989; Rintell, Mitchell 1989; Aijmer 1996; Lakoff 2001; Fahey 2005; Deutschmann 2006).

As Goffman (1967) observes, participants of a communicative act aim to maintain "ritual equilibrium" in communication, and apologizing is important since it helps to achieve this aim (Aijmer 1996). Similarly, George Leech observes that 'apologizing ... can be regarded as an acknowledgement of an imbalance in the relation between $\mathrm{s}$ and $\mathrm{h}$, and to some extent, as an attempt to restore the equilibrium' (1983: 125). Since apologies have the function of restoring or reducing equilibrium, they are referred to as 'remedial interchanges' (Owen 1983). 
Apologies are studied from different theoretical and methodological perspectives, such as semantics, speech act theory, sociolinguistic approach (see Aijmer 1996), the interdisciplinary approach of discourse analysis (Lakoff 2001) and corpus linguistics perspective (Deutschmann 2006). Being a culture-dependent phenomenon, conversational routines such as apologies are often studied in relation to cross-cultural variation (e.g. Wierzbicka 1991; Vollmer, Olshtain 1989; Blum-Kulka, House 1989; Wierzbicka 1991; Wolfston et al. 1989; Fahey 2005). A number of studies deal with the application of the pragmatics research and more specifically such speech acts as apologies to EFL (English as a Foreign Language) teaching. Such studies explore the importance of metapragmatic instruction on the speech act comprehension and production of non-native speakers (e.g. Rintell, Mitchell 1989; Bergman, Kasper 1993; Sbisà 1999; Eslami-Rasekh et al. 2004). Such studies clearly demonstrate practical applicability of pragmatic investigations of different speech acts.

Apologies are treated as ritualistic acts since speakers typically apologise in a relatively fixed way (Aijmer 1996: 80). Karin Aijmer (1996: 82) distinguishes two major sets of apologizing strategies, i.e. (1) explicit and implicit, (2) emotional and non-emotional strategies. Implicit apologies differ from the explicit ones as the former include no direct realization of an apology (e.g. sorry, apologise, excuse). If an apology is intensified (e.g. with the intensifier very), it is considered to be emotional.

Apologies are of special importance since they imply the speaker's guilt and thus are face-threatening (Olshtain 1989; Brown, Levinson 1994; Stenström 1994; Lakoff 2001). As Lakoff (2001: 201) points out, "apology, more than most speech acts, places psychological burden both on its maker and, less seriously, on its recipient”. According to Elite Olshtain (1989: 156), when the speaker decides to apologise, $\mathrm{s} /$ he "is willing to humiliate himself or herself to some extent and to admit to fault and responsibility for X". Lakoff (2001) further notes that apologizing benefits the addressee, not the speakers. Therefore, apologizing is a face-saving act for the hearer (Olshtain 1989). Apologies are especially 'threatening' if the apologiser is a powerful person; the face loss is more serious then (Lakoff 2001). However, it is important to note that though apologies are always face-threatening, "not making a necessary apology may occasion more serious face loss in the long run" (Lakoff 2001: 211).

As some previous investigations suggest, the influence of context on the use of apologies is of high importance. However, apologies have not been studied extensively in situational contexts. Speech acts in general should be studied by applying context-sensitive approaches. Jacob I. Mey (2001: 219) suggests that linguists should study what he calls situated speech acts since, "[s]peech acts, in order to be effective have to be situated. That is to say, they both rely on, and actively create, the situation in which they are realised". For instance, Joanna Cutting (2000) in her analysis of casual conversations among students demonstrates that speech acts in general have a special role in different discourse communities. Similarly, Roberta Kevelson (1982), who focuses on legal speech acts, argues that speech acts should be of major concern to linguists in context-sensitive analyses. The importance of apologies is demonstrated in Brent Poole's (2001) study of apologies in nonsynchronous computer mediated discourse among people from different cultural backgrounds. 
Some previous investigations attempted to take into account the situational context by using the method of discourse-completion questionnaires (e.g. Olshtain 1989; Wolfson et al. 1989; Vollmer, Olshtain 1989). The drawback of such studies is that the apologizing behaviour of speakers is not observed in natural situations but the respondents have to provide probable apologizing forms for different situations described in the questionnaire. Nevertheless, the results of these studies strongly suggest that apologies are context-dependent. Besides, as Olshtain's (1989) research shows, the form of apologies depends on the speaker's status, that is, intensification of apologies rises with lower status.

Some previous research demonstrates that an analysis of apologies can yield very revealing results if this analysis considers situational contexts. For instance, Kevin Avruch and Zheng Wang (2005) study the importance of apology in the context of international negotiation between the U.S. and China. Their article examines the role of apologizing in relation to cultural and linguistic differences in the course of the negotiation. Aijmer's (1996) study of the distribution of apologies over different texts shows that different apologies are restricted to different texts. For instance, sorry is not found in public speeches, but it prevails in other text types (sorry is most frequent in conversations). The importance of register, genre and key is emphasized in Lakoff's (2001) interdisciplinary model as an important aspect that has to be taken into consideration in an analysis of apologies.

Social variation in the use of apology formulae is stressed by Lakoff (2001) and has been studied extensively by Mats Deutschmann (2006), who examined the use of the most frequent apologies in the spoken part of the British National Corpus. Social variation was observed in relation to the speaker's age and their class identity, which suggests that different apologies are important social markers. However, only minor differences between different genders were noticed.

Investigations of apologies in business settings, however, are not numerous. Apologies have been studied by David A. Hoffman (1998) in employment termination cases to show what constitutes an effective apology and what legal consequences it may have. Hoffman (1998) shows that appropriate apologies are effective in resolving disputes. How the forms of apologizing are attained by Thai business people has been examined by Ruja Pholsward (2003). José Camilo Davila (2004: 1) provides some theoretical considerations concerning the issues related to apologizing and forgiveness in the context of workplace relationships. In his study apologies and forgiveness are related to the degree of sincerity and severity of offence. Davila offers a theoretical model of how to examine three "hypothesized antecedents of forgiveness": offence severity, the content of the apology and the perceived sincerity of the offender's sincerity.

\section{Discussion of the results}

The present investigation has revealed that different forms of apologies are important in three main respects. First of all, apologies differ considerably in their frequency. There are also some minor differences in their frequency in men's and women's speech. Another important aspect is the usage of apologies, which are highly formulaic and follow largely predictable patterns. Finally, in relation to 
apologies, it is important to take into account what is most commonly apologised for, since this is one of the important factors that can predetermine the pattern of an apology.

\subsection{Frequency of different forms of apologies}

The obtained data have revealed that different forms of apologies differ in their frequency. These differences are presented in Table 1, which provides not only general frequency of apologies but also their frequency in relation to gender.

Table 1. Frequency of different forms of apologies (per 1 million words)

\begin{tabular}{|l|c|c|c|c|c|}
\hline & sorry & excuse me & pardon & apologise & Total \\
\hline Women & 510.05 & 34.9 & 14.6 & 27.67 & 587.22 \\
\hline Men & 547.55 & 39.23 & 28.5 & 8.36 & 623.64 \\
\hline Total & 1057.6 & 74.13 & 43.1 & 36.03 & 1210.86 \\
\hline
\end{tabular}

Table 1 shows that apologies are rather frequent in business communication and total 1210.86 instances (see also Figure 1). The most noticeable differences can be observed between the total numbers of different forms of apologies. The data demonstrate that the most frequent apology is sorry, which occurs 1057.60 times per million. The other three apologies are considerably less frequent. Excuse me occurs 74.13 times; pardon occurs 43.1 times; apologise is even less frequent and occurs in 36.03 instances. Such a drastically higher frequency of sorry, as Figure 1 clearly demonstrates, can be explained by its usage peculiarities. It is the most neutral form of apologizing and thus it can be used in a much wider variety of situations. Apologise, being more formal than sorry, is of restricted usage since it may sound too emphatic. Excuse me is neutral in terms of its formality, but it is restricted mainly to the situations when the speaker wants to apologise for something embarrassing or rude that he/she will do. Pardon is mainly used when the speaker mishears and asks to repeat something.

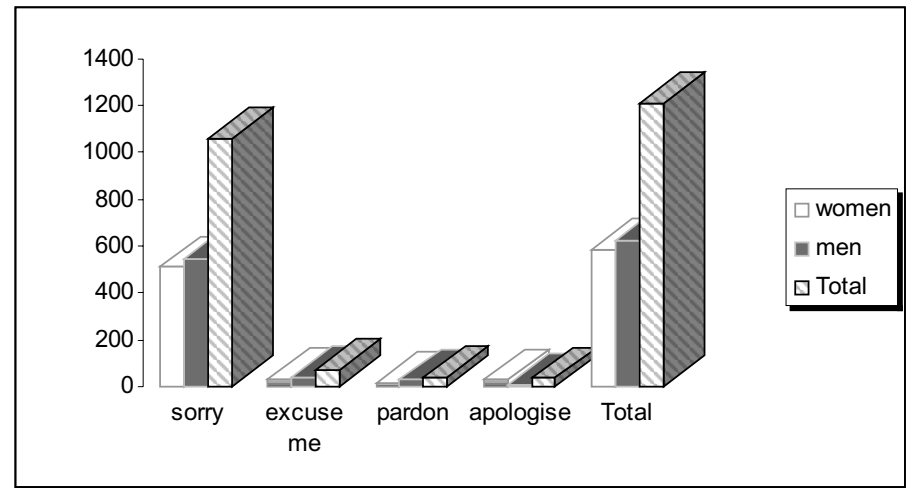

Figure 1. Distribution of different forms of apologies (frequency per 1 million words) 
Different usage aspects of different forms of apologies will be further discussed in Section 3.2, which focuses on discourse functions of these different forms.

As far as gender differences are concerned, very little variation has been observed in the collected data. Men and women almost do not differ in the total number of apologies used in business communication (587.22 and 623.64 occurrences respectively). Though men use apologies more frequently, the difference is too slight to be important. Though we hypothesized that women might be more apologetic, this hypothesis has not been corroborated. Both men and women act as professionals in business communication, and their gender seems not to influence their verbal behaviour.

However, some differences between men and women do exist. These differences are related to the preference of certain forms of apologies. Table 1 shows that women clearly prefer the form apologise (27.67 occurrences), which in men's speech is three times less frequent (8.36 occurrences). Meanwhile, the frequency of the most neutral apology form sorry is higher in men's speech (547.55 occurrences) than in women's speech (510.05 occurrences). Male speakers use pardon almost twice as frequently as women (28.5 and 14.6 instances respectively). Men also demonstrate a slight preference for the form excuse me, but the difference in its distribution is just minor (34.9 occurrences in women's speech and 39.23 occurrences in men's speech). These results suggest that women prefer more formal apologies, whereas men are more inclined to use less formal forms.

\subsection{Main usage patterns of different forms of apologies}

The investigation has revealed several main usage patterns of apologies. First of all, in the majority of cases apologies are neutral and occur without any modifications. In addition, typically shortened forms prevail. For instance, sorry is preferred to the full form I'm sorry, pardon is preferred to I beg your pardon (for similar results in general English, see Aijmer 1996: 91). However, some apologies can be loaded and thus are either emphatic or tentative. There also occur double apologies, apologies with self-justification and apologies preceded by an interjection or a pause filler. All these patterns are discussed in greater detail further in the present section. To indicate the speaker's gender in each case, abbreviations $\mathrm{M}$ for male and $\mathrm{F}$ for female speakers will be used after each example.

\subsubsection{Patterns of emphatic apologies}

Emphatic apologies are based on the principle 'maximum sincerity and respect'. The degree of sincerity and respect is increased by using different linguistic means of intensification, examples of which are provided in (1)-(5).

(1) Er, I must apologise again for what, er the way I addressed you, but of course with all these women equality er, movements going on, I never know whether its Mr, Mrs, or Ms. (M)

(2) Alan, Alan I'm sorry to interrupt you, I do apologize. (M) 
(3) A a again I am very very sorry. (M)

(4) I'm so sorry. (F)

(5) I'm awfully sorry... (M)

The examples above show that an apology is most commonly preceded by an intensifier (e.g. very, so, awfully). Another frequent intensifying device is the auxiliary do preceding the performative verb apologise, as in example (2). Finally, the performative verb apologise can be preceded by the modal verb must, which expresses strong obligation, to strengthen the illocutionary force of the apologizing utterance. In all these cases, the speaker maximally increases the threat to his/her own positive face, but by doing this, the speaker maximally reduces the threat to the hearer's face. Such techniques allow the speaker to preserve the stability of the relationship. Interestingly, in comparison to tentative apologies, which will be discussed below, emphatic apologies prevail in the collected data. This tendency suggests that speakers are more interested in maintaining a stable relationship and expressing positive attitudes to the interlocutors rather than saving their own face.

\subsubsection{Compound apologies}

Compound apologies, as referred to by Aijmer (1996), are closely related to emphatic apologies since the repetition of an apology strengthens its effect, as in examples (6)-(8).

(6) Right, first of all I'd like to apologize for the fact that Alan's report and my report especially the first half, are very similar. I'm sorry about that. (F)

(7) Oh beg your pardon I'm sorry I thought you said internal right. (M)

(8) And also sorry, excuse me like the other points there are you a smoker, no my wife does, she smokes twenty... (M)

Two apologies can follow one another in the same utterance, as in (7)-(8), or they can occur in two subsequent utterances, as in (6).

\subsubsection{Patterns of tentative apologies}

As has already been mentioned, tentative apologies are not as frequent as emphatic apologies. Tentative apologies contain mitigating devices that lessen the strength of the apology and make it less sincere, as can be seen in examples (9)-(11).

(9) I should perhaps apologize on behalf of the hotel for the temperature in the room this morning er I stayed here last night and woke up to find that not only was there no heat in the radiators, but there was no heat in the hot water. There wasn't any hot water. They had a major boiler breakdown last 
night. Two boilers failed. Er so, so there's a distinct lack of central heating. Even more remarkable lack of hot water so (M)

(10) I'd like apologize for the room, it's er too cold really. (M)

(11) I I feel a bit sorry for for some of the counters because they can see certain on one palette for instance, I found there were three sorts of bags. (M)

In example (9), the apology is made tentative by means of modality. The utterance starts with the modal should and the adverb perhaps, both of which express lack of commitment (cf. I must apologize to see the contrast). In addition, the speaker does not make a personal apology, but apologises on behalf of the hotel, which allows the speaker to lessen personal responsibility and also face-threat. In example (10), the verb apologise is preceded by ' $d$ like, which weakens the force of the apology by making it less straightforward. In example (11), the mitigator $a$ bit makes the apology less forceful. The examples above suggest that tentative apologies are less sincere than emphatic apologies and are based on the principle "minimum facethreat' for the apologiser.

\subsubsection{Apologies with a self-justification}

In a great number of instances apologies are followed by a self-justification. Such self-justifications can be seen as special cases of face-saving and thus can be related to tentative apologies. Some examples of such extended apologies with self-justifying arguments are provided in (12)-(14).

(12) I'd like apologise for the room, it's er too cold really. I booked the conference not realising it was gonna be the control room by this time, and then this morning I turned up to find out we can't put the lights on without getting behind the bar, and we can't get behind the bar so that's why this er (M)

(13) I think what we have to understand, colleagues, is that this report actually is put to bed, print-wise, well in advance of this Congress. It doesn't in any way claim to be an absolutely up to the minute report of absolutely everything that we've done in the previously twelve months since last Congress, and quite frankly, it just could not be that. So, we do apologize, but hope you'll understand er, the delegate particularly, that we just cannot ensure that the report has got absolutely everything in it. (M)

(14) Erm I'm sorry about yesterday, but I just couldn't come. (F)

The examples above can be treated as cases of face-repair since the self-justifying explanations are the speakers' attempts to shield themselves. The speakers in examples (12)-(14) do apologise and admit their fault to demonstrate their sincerity, but simultaneously they disclaim their fault or try to lessen it by referring to some external circumstances that made their faults inevitable. As can be seen in examples (13) and (14), self-justifications are often introduced by the conjunction but (such constructions are called 'but-prefaces' by Baker 1975, as cited in Lakoff 2001). Thus 
apologies with a self-justification are well-balanced apologies that both express sincerity and respect to the speaker; they also minimize the face-threat.

\subsubsection{Patterns with interjections and pause fillers}

In a number of cases the interjection oh precedes the apology sorry, e.g. Oh sorry. See also example (15), which contains an interjection and a discourse marker in the utterance initial position.

(15) Oh, well, sorry about that er Marlene. (M)

Sometimes a pause filler precedes an apology:

(16) Erm I'm sorry about yesterday, but I just couldn't come. (F)

(17) $E r$ let me apologize if the motion appears a little vague. (M)

The use of a pause filler in (16) and (17) allows the speaker to make a delay before uttering the apology.

Thus the investigation has shown that apologies are highly routinized and follow a largely predictable pattern. Apologies can have a different degree of force, depending on which several main types of apologies can be distinguished. First of all, apologies can be emphatic; in such a case, they primarily express the speaker's sincerity. Such apologies contain different intensifiers or double apologies. Tentative apologies, in contrast, are primarily face-oriented and contain different mitigating devices. Apologies with self-justifications are a balanced type of apologies since they both meet the requirement of sincerity and address the speaker's need for face-repair.

\subsection{What is apologised for in business communication?}

Another important aspect to take into account in relation to apologies is the faults that the speakers apologise for. On the basis of the data, two main reasons for apologies have been distinguished: (a) apologies for linguistic malfunctioning and (b) apologies for non-linguistic malfunctioning.

\subsubsection{Apologies for linguistic malfunctioning (metalingual uses)}

Most frequently apologies are made in cases of linguistic malfunctioning. Since in such instances the speaker comments on the discourse that is being produced, such uses of apologies will be called metalingual uses; see, for instance, example (18).

(18) However, the major problem, and you Ma'am have already touched upon this as well as the Chairman and I'm sorry to be repetitive but we do serve all yachtsmen, two and a half to three million of them whilst being financially supported by only sixty five thousand of them. (M) 
In example (18), the speaker comments on what is being said and thus apologises for being repetitive. There are numerous other cases of linguistic malfunctioning, some of which are briefly discussed below.

\section{- Interruption}

To apologise for an interruption, different forms of apologies are used, as can be seen in (19)-(23).

(19) Robert Robert, excuse me, do you know what the er SSP allowance is? (F)

(20) Excuse me a second I'll just do a quick (M)

(21) Sorry to interrupt you but there's nobody around at all and I've, yeah if I can just $(\mathrm{F})$

(22) Oh actually sorry, if I could just add a little bit to that. (M)

(23) Colleague, just one second, I do apologise for, for cutting is, but colleagues if you're, if it's your intention to leave Congress for a few moments please do it as quietly as possible. (M)

\section{- Disagreement (face-repair)}

In a number of cases an apology with sorry is used to mitigate disagreement, as in examples (24)-(26).

(24) I'm sorry if that's causing people a problem but that is basic human right. (F)

(25) I'm sorry Barbara, but time's a budget item with me these days, I can't wade through all this. (F)

(26) I'm sorry to say this, but the people that say money isn't everything, are the ones who've got it, aren't they? (M)

Usually, as the examples above suggest, in cases of disagreement an apology precedes a clause with but. Such uses of sorry can be treated as cases of facerepair. Since disagreement is an FTA, an apology in such instances functions as a mitigating device. By apologizing, the speaker admits the threat to the hearer's face and thus attempts to maintain the stability of the relationship.

\section{- Asking for repetition}

Apologies (usu. sorry) are also used in the speakers requests for repetition, as demonstrated in example (27).

(27) Sorry can you say again? (F)

\section{- Not being able to follow}

(28) Sorry I'm not, not with you. (F)

(29) Sorry, what did you say? (M) 


\section{- Being too detailed}

(30) I'm sorry, I'm sorry I've been a bit steady getting there, but I think it's an important issue to tackle that... (M)

\section{- Self-correction}

Apologies in cases of self-correction are rather recurrent in the obtained data; see examples (31)-(34), where the corrected items have been underlined. As the examples suggest, the most frequent apology form in such cases is sorry.

(31) And divorce is or sorry, remarriage is not allowed for members of the Anglican Church. (F)

(32) We found that patients who were significantly younger er sorry we found that patients who were counseled for retrograde ejaculation were significantly younger (M)

(33) I had a hundred and twenty seven percent er sorry twenty seven percent above target er... (M)

(34) The Torries' reduction of public borrowing has been excuse me has seen many public services destroyed or disappeared forever. (M)

As examples (31)-(34) show, the routine of such apologies follows the pattern corrected information + apology + correct information.

It has to be noted that in requests for repetition, apologies for being unable to follow the speaker and apologies for self-correction, the apologizing pattern is usually very simple. A certain apology form without any elaboration is inserted in the utterance just to mark the speaker's awareness of some malfunctioning. With regard to the sincerity principle, such apologies are very neutral and routinized.

\subsubsection{Apologies for non-linguistic malfunctioning}

Apologies for non-linguistic malfunctioning are not as frequent as the ones for linguistic malfunctioning. Some examples of such apologies are provided below in (35)-(38).

(35) Now I'm sorry I haven't brought an acetate. (F)

(36) Sorry, I was dozing off over there. (F)

(37) I'm sorry I'm late. (M)

(38) I'm sorry I can't give you that. (M)

In the cases above, speakers apologise for their failure to perform something, as in (35), for some misbehaviour, as in (36) and (37), and refusal to do something, as in (38). As examples (35)-(38) show, all these cases of non-linguistic malfunctioning are just minor wrongdoings with a relatively low degree of the severity of the offence. 


\section{Summary and conclusion}

The data have revealed that apologies are rather frequent in business communication; in the sub-corpus under investigation there occur 1210.86 cases of apologies. Apologies are slightly more frequent in men's than in women's speech, but this difference is too slight to be important (for similar results, see Deutschmann 2006). Interestingly, as the data show, there are some gender differences in the frequency of different forms of apology in men's and women's speech. The most neutral apology sorry is considerably more frequent in men's speech, whereas the most formal apologies with the performative verb apologise are more frequent in women's speech. This tendency suggests that women tend to use more formal forms of apology, at least in business settings. However, this tendency needs further testing on a bigger corpus.

Another observation in relation to frequency is that different types of apologies differ drastically in their frequency. The data show that most commonly apologies include sorry; apologies with the verb apologise are the least frequent ones. Similar results were obtained in Aijmer's (1996) corpus analysis of apologies, which were studied in general English without taking into account situational variation. Her data from the London-Lund Corpus show that apologies with sorry are the most frequent ones, whereas those with apologise are least frequent. The considerably higher frequency of sorry suggests, as Aijmer (1996: 84) observes, that sorry has become the most neutral and least marked routine. Apologise, according to her, is restricted mainly to formal situations (ibid.).

As for the linguistic patterns of apologies, they are highly routinized, or formulaic. Apologies can be of different degrees of strength, some being highly emphatic and others being rather tentative (cf. intensified and downgraded apologies in Olshtain 1989). Emphatic apologies (e.g. I must apologise, I do apologise) are based on the principle of 'maximum sincerity and respect', whereas tentative apologies (e.g. oh well I apologise for that then) are based on the principle of "minimum face-threat". However, in business communication apologies are most commonly very neutral and include the adverb sorry without any intensifiers or mitigators.

An interesting category of apologies includes those cases when an apology is followed by a but-explanation. Olshtain (1989: 158) refers to them as downgraded apologies, which raise "the question whether an apology was even necessary". Such apologies attempt to minimize the seriousness of the violation.

\section{References}

Aijmer, Karin 1996. Conversational Routines in English: Convention and Creativity. London and New York: Longman.

Avruch, Kevin; Wang, Zheng 2005. Culture, apology, and international negotiation: The case of the Sino-U.S. 'Spy Plane' crisis. - International Negotiation 10/2, 337-354.

Baker, Charlotte L. 1975. This is just a first approximation, but... - T. J. San, J. L. Vance, R. E. Grossman (Eds.). Papers from the Eleventh Regional Meeting of the Chicago Linguistic Society. Chicago: Chicago Linguistic Society, 37-47.

Bergman, Marc L.; Kasper, Gabriele 1993. Perception and performance in native and nonnative apology. - Gabriele Kasper, Shoshana Blum-Kulka (Eds.). Interlanguage Pragmatics. Oxford: Oxford University Press, 82-107. 
Blum-Kulka, Shoshana; House, Juliane 1989. Cross-cultural and situational variation in requesting behaviour. - Shoshana Blum-Kulka, Juliane House, Gabriel Kasper (Eds.). Cross-Cultural Pragmatics. Requests and Apologies. Norwood: Alex Publishing Corporation, 123-154.

Brown, Penelope; Levinson, Stephen C. 1994. Politeness. Some Universals in Language Usage. Cambridge: Cambridge University Press.

Cutting, Joanna 2000. Analysing the Language of Discourse Communities. Amsterdam: Elsevier.

Davila, José Camilo 2004. Forgiveness as a function of offence severity, apology extensiveness, and perceived sincerity. - htttp://www.agrh2004-esg.uqam.ca/pdf/Tome2/Davila. pdf (20.07.2006).

Deutschmann, Mats 2006. Social variation in the use of apology formulae in the British National Corpus. - Antoinette Renouf, Andrew Kehoe (Eds.). The Changing Face of Corpus Linguistics. Language and Computers 55. Amsterdam/New York: Rodopi, 205-221.

Eslami-Rasekh, Zohreh; Eslami-Rasekh, Abbas; Fatahi, Azizollah 2004. The effect of explicit metapragmatic instruction on the speech act awareness of advanced EFL students. - Teaching English as a Second Foreign Language. Electronic Journal 8 (2). http://www-writing.berkeley.edu/tesl-ej/ej3o/a2.html (15.07.2006).

Goffman, Erving 1967. Interaction Ritual: Essays in Face-to-Face Behaviour. New York: Doubleday Anchor.

Hahey, María Palma 2005. Speech acts as intercultural danger zones: A cross-cultural comparison of the speech act of apologizing in Irish and Chilean soap operas. - Intercultural Communication 8. http://www.immi.se/intercultural/nr8/palma.htm (19.07.2006).

Hoffman, David A. 1998. The Use of Apology in Employment Cases. - http://bostonlawcollaborative.com/documents/2005-07-apology-article.pdf (19.07.2006).

Kevelson, Roberta 1982. Language and legal speech acts: Decisions. - Robert Di Pietro (Ed.). Linguistics and the Professions. Proceedings of the Second Annual Delaware Symposium on Language Studies. Norwood: ABLEX Publishing Corporation, 121-131.

Lakoff, Robin Tolmach 2001. Nine ways of looking at apologies: The necessity for interdisciplinary theory and method in discourse analysis. - Deborah Schiffrin, Deborah Tannen, Heidi E. Hamilton (Eds.). The Handbook of Discourse Analysis. Oxford: Blackwell, 199-214.

Leech, George 1983. Principles of Pragmatics. London, New York: Longman.

Mey, Jacob L. 2001. Pragmatics. An Introduction. 2nd ed. Oxford: Blackwell Publishers.

Olshtain, Elite 1989. Apologies across languages. - Shoshana Blum-Kulka, Juliane House, Gabriel Kasper (Eds.). Cross-Cultural Pragmatics. Requests and Apologies. Norwood: Alex Publishing Corporation, 155-173.

Owen, Marion 1983. Apologies and Remedial Interchanges. Berlin, New York, Amsterdam: Mouton Publishers.

Pholsward, Ruja 2003. Evaluation of language functions used by Thai business people. http:/www.utcc.ac.th/article_research/PDF/utccforum/EvaluationofLanguage.pdf (20.07.2006).

Poole, Brent 2001. Apologies in computer-mediated communication. - Pragmatic Matters. JALT Pragmatics SIG Newsletter 2/3, 5-7.

Rintell, Ellen M.; Mitchell, Candace J. 1989. Studying requests and apologies: An inquiry into method. - Shoshana Blum-Kulka, Juliane House, Gabriel Kasper (Eds.). CrossCultural Pragmatics. Requests and Apologies. Norwood: Alex Publishing Corporation, 248-272.

Sbisà, Marina 1999. The room for negotiation in apologizing: Evidence from the Italian speech act of scusari. Paper read at the International Conference Pragma99 "Pragmat- 
ics and Negotiation", Tel Aviv and Jerusalem, 13-16 June. http://www.univ.trieste. it/ dipfilo/sbisa/scuspap.html (15.07.2006).

Stenström, Ana-Brita 1994. An Introduction to Spoken Interaction. London, New York: Longman.

Vollmer, Helmut J.; Olshtain, Elite 1989. The language of apologies in German. - Shoshana Blum-Kulka, Juliane House, Gabriel Kasper (Eds.). Cross-Cultural Pragmatics. Requests and Apologies. Norwood: Alex Publishing Corporation, 197-220.

Wierzbicka, Anna 1991. Cross-Cultural Pragmatics. The Semantics of Human Interaction. Berlin, New York: Mouton de Gruyter.

Wolfston, Nessa; Marmor, Thomas; Jones, Steve 1989. Problems in the comparison of speech acts across cultures. - Shoshana Blum-Kulka, Juliane House, Gabriel Kasper (Eds.). Cross-Cultural Pragmatics. Requests and Apologies. Norwood: Alex Publishing Corporation, 174-196.

Laura Čubajevaitè teaches in the Regional Studies Department, Vytautas Magnus University, Lithuania, Her research interests include foreign language teaching methodology and quality, and intercultural communication.

I.cubajevaite@trs.vdu.lt.

Jüratè Ruzaitè teaches in the Department of English Philology, Vytautas Magnus University, Lithuania, Her research interests include discourse analysis (esp. spoken academic discourse), discourse and ideology, corpus linguistics, and vague language.

j.ruzaite@hmf.vdu.lt. 


\section{VABANDUSED TÖÖSUHTLUSES}

\section{Laura Čubajevaitè, Jūratè Ruzaitè}

Vytautas Magnuse nimeline Kaunase Ülikool

Artiklis analüüsitakse ingliskeelse suulise töösuhtluse vabandamistavasid. Vabandused kui mina-pilti ohustavad aktid on suhtluses eriti olulised. Kuivõrd vabandused väljendavad siirust ja on parandusaktid, aitab vabandamine parandada vastastikust lugupidamist ja säilitada stabiilseid suhteid kolleegide vahel, mis on töösuhtluses eriti oluline. Artikkel keskendub neljale eksplitsiitse vabandamise väljendile: sorry, I apologise, pardon ja excuse me. Andmed pärinevad korpuse British National Corpus allkorpusest, mis sisaldab 1321844 sõne mahus tööalaste vestluste litereeringuid.

Meeste kõnes esineb vabandusi veidi sagedamini kui naistel. Erinevusi leidub eri vabandusväljendite kasutamises. Kõige neutraalsem sorry on märgatavalt sagedasem meeste kõnes, formaalseim vabandus performatiivverbiga apologise aga naiste kõnes. Nähtavasti kalduvad naised formaalsema vabandamise poole, vähemalt töökeskkonnas. Suuresti erinevad eri vabandusväljendite üldised sagedused. Kõige sagedasem on sorry, kõige vähem esineb apologise.

Vabandusväljendite mallid on üpris kivistunud. Vabandused võivad olla eri tugevusega, mõned neist on väga emfaatilised, teised üsna ebakindlad. Emfaatilised vabandused põhinevad maksimaalsel siirusel ja lugupidamisel, ebakindlad aga mina-pildi minimaalsel ohustamisel. Omapärane kategooria on vabandused koos järgneva selgitava but-algulise lausega.

Võtmesõnad: vabandamine, mina-pildi säästmine, viisakus, sugu, situatsioonikontekst, inglise keel 